\title{
6. A foreign flower no more Tongan diasporic media and the 2014 Tongan election
}

\begin{abstract}
The use of social media and the involvement of diasporic population in politics is a growing trend among diasporic Polynesian communities and Island politicians. Auckland-based Tongan media, which are the focus of this article, appear to have had an effect on voter behaviour in the 2014 Tongan elections. Using the Auckland-based news site Kaniva News as a case study and drawing on interviews with Tongan journalists, this article sets out to show the links between the development of online media among the Tongan diaspora, the rise of 'Akilisi Pohiva's democracy movement and the mediated involvement of New Zealand's Tongan community in that democratic process. Similar developments have also been noted in Fiji and the Cook Islands where online media played an important part in recent elections.
\end{abstract}

Keywords: Kaniva News, Tonga, diaspora, diasporic media, democracy, elections, 'Akilisi Pohiva

\section{PHILIPCASS \\ Unitec, Auckland}

N RECENT years, Pacific Islanders from the diasporic Polynesian communities have used metropolitan centres as points from which they have participated in democratic campaigns that combine traditional social structures and extended family functions, augmented by digital media. The way the democratic process has been conducted reflects a process of adaptation and adoption by communities taking part in their own culturally adapted versions of Parliamentary democracy, often mediated by digital platforms. Rather than being what The Fiji Times once called 'a foreign flower' (Larmour, 1994), the democratic process has, like so much, been adapted to the fa'a Pasifika.

The use of social media and the involvement of diasporic communities is a growing trend among Island politicians. Fijians have been heavy users of Facebook and other media in recent years. There was fierce debate on Fijian websites about issues relating to Fiji and the most recent national elections. In 2014, the Fijian Prime Minister, Voreqe Bainimarama visited Auckland to speak to Fijians living in Auckland, who are able to vote (Field, 2014). The former Fijian Prime Minister, ex-colonel Sitiveni Rabuka, went to the Democracy in the Pacific conference at the University of Canterbury in 2012 to talk about politics and to boost 
his own profile among overseas Fijians (Mann \& Turner, 2012). Both Kailahi (2015a) and Latu (2014a) attributed the influence of Tongans in Auckland to the importance of their remittances to the kingdom's economy. In the Cook Islands, politicians turned to social media during the 2014 elections, with Democratic Party campaign manager Piltz Napa saying the party's Facebook page had been viewed by many people living outside the island nation who wanted to be kept informed (RNZI 2014a \& b; Technology Plays a Part in Election, 2014)

Auckland-based Tongan media, which are the focus of this article, appear to have had an effect on voting patterns and voter behaviour in the 2014 Tongan elections. Tongan politicians conducted part of their campaign in New Zealand because even though Tongans living in New Zealand cannot vote in Tonga, they used new media to influence relatives at home, aided and abetted by diasporic media located in New Zealand's largest city. These trends reflect the development of online media as political fora noted by Georgiou (2004) and on the growing influence of diasporic media on their home countries predicted by Karim (1998). Barcham et al (2009) contend that electronic communication has played an important part in the flow of ideas and knowledge between members of Polynesian diasporic communities and their home countries:

Electronic forums ensure that many members of the Polynesian diasporaboth first-and second-generation migrants-still feel in touch with events back 'home'. Planet Tonga (http://www.planet-tonga.com) receives over 1 million 'hits' per month, thus providing a popular forum for communication among the Tongan diaspora: 'Tongan participants from all over the world ... are eager to communicate with one another, share their experiences and opinions, and access news and information about Tonga itself, often sparking an interest in Tonga that was either absent or minimal before' (Lee, 2004, p. 247)... [ ] ... electronic forums have allowed people to express concerns about their society or culture that could not be expressed elsewhere; for example, challenging the Tongan monarchy.

Writing in 2004, Lee (p. 242) noted that:

The 'long distance' Tongan nationalists are becoming increasingly vocal, as they become more concerned for the future of their homeland, and they are likely to seek ways to be more directly involved. In the not too distant future it would not be surprising if at least some of the overseas population unites to demand more of a say in the nation-building process.

As this article makes clear, Lee's prediction about the demands of the diasporic community for a greater say has come true. It also makes clear that the role of the diasporic media identified by Spoonley (cited by Papoutsaki, 2008) has gone far beyond one of serving the local diasporic community in a simplistic 
manner or connecting it with its country of origin. De Souza's (2014) depiction of the functions fulfilled by the diasporic media (boosterism, assimilation etc) may also be usefully revised in light of the political uses to which diasporic online media are being put in the Pacific.

\section{Tongans in Auckland}

According to a PACMAS report (Papoutsaki et al, 2013) the Tongan population in Auckland has continued to grow in recent years. In 2006, Tongans were the third largest Pacific ethnic group in New Zealand, making up 50,478 or 19 percent of New Zealand's Pacific population $(265,974)$. The Tongan population increased by 24 percent $(9,763)$ between 2001 and 2006. According to the 2013 census there were 60,336 Tongans living in New Zealand, which makes up 1.5 percent of the total New Zealand population (Statistics New Zealand, 2013). The population in Tonga is 104,500. Estimates by Statistics New Zealand indicate that the growth of the Asian population will be the greatest, from the 2006 figure of 10 percent to 16 percent in 2026 compared to Pacific peoples from 7 percent to 10 percent and Māori from 15 to 16 percent (Ministry of Social Development, 2010, cited by Noronha). Tongans are the fastest growing community in New Zealand, with a birth rate twice the national average (Te Ara, 2014).

There are other substantial Pacific Islands diasporae in New Zealand. In many cases the population in New Zealand far outweighs that in the home country. Among the Tongan diaspora in New Zealand:

- 61 percent of the Tongan community speak Tongan

- But there is concern about second and third generation language loss

- 64 percent of Tongan adults have a formal educational qualification (secondary school or post-school qualification).

- 80 percent $(40,140)$ of New Zealand's Tongan population lives in the Auckland region

- Tongans born in New Zealand account for 56 percent $(27,693)$ of the total Tongan population.

- People may identify as Tongan even when they have multiple ethnic backgrounds.

\section{Tongan media}

According to Kailahi, (2015a) there are strong media content and communication flows from Tonga to New Zealand and to diasporae in Australia and the United States. There is a strong awareness of the different audiences's needs, desires and capabilities, especially for those Tongans living in other countries. The PACMAS report on the media in Tonga highlights the kingdom's active online community, especially among the diaspora who access Tongan news and other content (Papoutsaki et al, 2013). The report highlights Tonga's 
active online community, especially among the diaspora who access Tongan news and other content. This also includes the use of online social networks. Family websites with large networks are an emerging phenomenon. Internet access and using email are common ways for families to stay connected. However, research at Deakin University suggests that Tongans in New Zealand are far more likely to use Tongan media, to be aware of what is happening in the kingdom or to participate in domestic issues than Tongans in Australia (Pyke et al, 2012).

\section{A new public sphere}

Castells (2008) argues that the public sphere, as articulated in different ways at different times and through different kinds of technology and space, is the cornerstone of civil society and thus of democracy. He argues that the world has moved towards a situation in which it is possible to move from purely domestic to global public spheres and forms of civil society.

... the public sphere as the space of debate on public affairs has ... shifted from the national to the global and is increasingly constructed around global communication networks. Public diplomacy, as the diplomacy of the public, not of the government, intervenes in this global public sphere, laying the ground for traditional forms of diplomacy to act beyond the strict negotiation of power relationships by building on shared cultural meaning, the essence of communication.

Kailahi argues that Tongans living outside the kingdom have connected and formed a new 'public sphere' online through Facebook. This virtual community has many different pages dedicated to Tongan diaspora, including the 'I'm proud to be Tongan' page which has 57,592 members; Royal Tongan Dynasties/Nobles Forum which has 18,769; Tonganow Online Community which is a closed membership of 5855; and the Tonga closed group page consisting of 14,634 members ${ }^{1}$ (Kailahi, 2015a). Posts to I'm Proud to be Tongan and Tonganow are in a mixture of English and Tongan while posts to the royal forums are in English.

These pages allow Tongans living outside of the kingdom to freely express their opinions, thoughts and promote discussion about all things Tongan within the sites's rules and regulations.

What we see happening with the diasporic media in Auckland, the creation of online communities and the elections and political processes in the Pacificand in this case, specifically in Tonga, is a reflection - at least in embryo - of Castell's vision of a global (or, because it is diasporic, globalised) civil society.

Tongans in Auckland use Tongan news and social media outlets to maintain cultural, family or political links. Kailahi maintains that the first two are priorities 
for Tongan families and is supported in her claim by Kaniva News editor Kalino Latu, who said:

Tongan news and social media are the only avenues available to the majority of Tongans living overseas to follow up current affairs and news at home and abroad. They keep them up-to-date with the cultural, family and political happenings in Tonga. (Latu, 2015e)

According to John Pulu of Tagata Pasifika, social media have become a powerful tool and source of information among the dispersed Tongan community. They allow families to maintain their links to people in Tonga and this can influence families. He said Tongan politicians were aware of its influence and most politicians were on Facebook (Pulu, 2015).

If we accept that participation in the public sphere is a vital part of democracy, then Tongans certainly take part in democratic campaigns, but in a way that is very specific to the intersection of digital media with the Tongan community in New Zealand and the drive towards democracy in the kingdom led by 'Akilisi Pohiva. To criticise members of the royal family, to try to hold them to account for their behaviour on the internet, is a democratic act. To try to influence the media by sending them images and stories that attack government inefficiency, corruption and malfeasance is to be part of the democratic process.

\section{Prince Ata's baptism}

One example of the use of diasporic media to criticise the royal family occurred when the long running saga of whether Prince Ata would become a Mormon finally came to a head. His baptism at a secret ceremony in Honolulu split leading figures in the Church of Jesus Christ of Latter Day Saints (LDS) and their supporters, as recorded in Kaniva News (Latu, 2015c).

Hon. Semisi Sika, the President of the Church's Liahona High School Global Alumni, lashed out on Facebook, calling the baptism an act of 'terrorism', 'attention seeking' and alleging that Prince Ata had been bribed.

Hon. Sika, Chairman of Tonga's Parliamentary Whole House Committee, accused Vava'u Governor Lord Fulivai of being behind the plan to baptise Prince Ata.

'Why does Lord Fulivai keeps silent in Vava'u?' Hon. Sika asked in Tongan.

Supporters of the Prince's baptism hit back on Facebook.

Loseline Hola Uasike wrote in Tongan: 'Why is God's mission called terrorism? I am afraid Bin Laden was involved with the Church's work. The cup has been spilled and cannot be collected. This issue should have not been brought to Facebook by church members as it would cause a rift with other churches.' 
One commentator, Sitalingi Tovo, claimed on Facebook that an LDS leader in Salt Lake City said those involved in the baptism should be expelled from the Church.

\section{Politics in Tonga}

Tonga's new political system, which was implemented in 2010, introduced an electoral system comprising two electorates: The hereditary land-holding nobles, plus nine Life Peers (honorary Nobles), who elect nine hereditary Nobles. The rest of the population elects 17 representatives, 10 of them on the main island, Tongatapu. The kingdom's current political system was designed to have all members of the unicameral parliament elected every four years. The system does not recognise political parties; instead MPs are meant to represent the 'whole country'.

However, Prime Minister 'Akilisi Pohiva, whose decades of struggle led to the changes in Tonga's political system, leads what is a de facto Democratic Party that now rules with the assistance of several independents. The Democratic Party became an effective opposition after the first democratic election in 2010. Tonga's democratic system is an adaptation of the Westminster system and with its hereditary peers and royal family, it is probably closer to the British system than most in the Commonwealth. However, given the power of the nobles and royal family and the kingdom's endemic corruption, it is rather closer to the Britain of the Hanoverians than the second Elizabethan era. Pohiva has made it clear he is not a republican and regards democracy as safeguarding Tonga's traditional social structure:

Pohiva told an Auckland audience that democracy would provide the people's right to rule their government and safeguard the monarch from becoming subject to accusations by taxpayers because of any decision he made. He said he regarded those who opposed his democratic views as opportunists who used the king and the royals for personal gain and at times over-stepped the social boundaries, which discredited the monarchy. (Latu, 2014b)

\section{The 2014 election}

Before the election campaign Pohiva visited Auckland where he had established a power base many decades ago after facing major legal and other problems in Tonga. The size and influence of the Tongan diaspora in New Zealand has meant that it has begun to exercise an influence on life in the kingdom. Many people in Tonga are heavily reliant on remittances and the size of the flow of money into and out of the kingdom is such that the government expects to be able to fund a substantial part of the building programme for the South Pacific Games by a modest increase of charges on foreign exchange transactions. 
The period before the election was marked by upheavals in the Democratic group, much of it carried out in the open in the pages of Pohiva's newspaper, $K e$ 'lea. There was great disquiet in the party when Pohiva appeared to support a candidates' list drawn up by his son-in-law, who was then editor of the newspaper. Local newspapers in Tonga and the New Zealand Tongan Development Society proposed their own Democratic Party candidates for the election. The New Zealand Tongan Development Society said it would support those MPs who were loyal to the Party after two members, Sangastar Saulala and Siosifa Tu'utafaiva, defected to the government of PM Lord Tu'ivakano.

Pohiva's Democratic party won nine seats in the 2014 elections, fewer than the 12 secured in 2010, but this time Pohiva was able to secure alliances in a way he could not after the previous election. Deals with independents secured the alliances he needed to ensure his election by his fellow parliamentarians as Prime Minister. The parliamentarians, who represent commoners and Nobles, voted 15-11 for Pohiva (Field, 2014).

Since then Pohiva has been accused of nepotism for appointing his son as his secretary. Pohiva has sacked several party members, dropped others from the candidates' list and often acted without apparently seeking advice from the party hierarchy or cabinet.

Under the Tongan electoral system, non-resident Tongans cannot vote. However, if they have maintained a presence on the Tongan electoral roll and have lived in the kingdom for three months prior to an election, they may stand for Parliament. Theoretically a Tongan living in New Zealand could go back to Tonga, live there for three months and be elected to Parliament. Many Auckland Tongans would like to vote in the Tongan elections and have suggested that they be able to do this either online or by voting at the official Tongan residence in Auckland, 'Atalanga. This proposal has been rejected by the Tongan government, with the Attorney-General citing cost as a major factor. It is worth keeping in mind Lee's suggestion (2004) that if the overseas Tongans who have retained Tongan citizenship were allowed to vote, it could make a significant difference to the outcome of elections.

Tongan politicians used the Tongan diasporic media to carry their messages during the election. Stories and documents were leaked and statements released to the media and it is clear that the Auckland-based media were targeted as much as the domestic media. Kailahi points out that that Tongans in Auckland are in a strong position to use new media to influence relatives at home, aided and abetted by diasporic media located in New Zealand's largest city.

(Politicians) know with the amount of remittances sent from New Zealand to Tonga, families here will probably have an influence on their kainga (extended family) back in Tonga. It's also a way for them to keep connected 
with the diaspora who live here because Tongans still keep connected with what is happening back in the Islands. (Kailahi, 2015b)

Latu said Tongans in New Zealand had been actively interested in Tonga's politics since the 1990s, especially in supporting 'Akilisi Pohiva and the democrats. That support grew significantly in the last election. This had led to a growing influence from Tongans in Auckland and attempts to influence their family in Tonga on the way to vote in 2014 (Latu, 2015d).

\section{After the election}

After the Tongan election, Pohiva travelled to Auckland where he spoke to about 500 people at Lotofale'ia Methodist Church hall (Latu, 2015b). During the meeting he was asked many questions about domestic matters, including the employment of civil servants, religion and the role of China in Tonga. Tongans in Auckland clearly felt they have a right to a say in what is happening in the kingdom. According to Latu, this is because Tongans in Auckland think differently about politics to their families at home because they live in a country where dissent is expected and tolerated. The first Tongan-speaking Member of New Zealand's Parliament, Jenny Salesa, was elected in 2014.

Tonga's democracy is still in its early stages while New Zealand had it many decades ago. Tongans in Auckland look at politics as one of the avenues that brings them fortune and greater opportunities in New Zealand. In Tonga people look at politics as something that could bring good governance, transparency and accountability to the nation. (Latu, 2015e)

Pulu agreed, saying that Tongans in Auckland were different from their relatives in the kingdom. He said they came to New Zealand and discovered that it was permissible to disagree (Pulu, 2015).

\section{Nepotism}

That freedom to disagree has been extended to Pohiva himself. His controversial appointment of his son as his private secretary caused an uproar which spilled over into Facebook (Latu, 2015a).

Olivia Ve'etutu T said: 'PM does not look good with it in the international level after all those numerous years of calling for good governance!'

Arthur Fonua said: ' ...the appointment of his own son does not enhance or strengthen his own foundational vision of inclusion ... not well thought out from a democratic perspective and metric".

Senolita Swan commented: 'What a shame...Do what you preach... I had such a high hope for this PM.' 
However, Pohiva supporters rallied around.

Sione Talanoa Fifita Mālie commented on the Democracy for Tonga Facebook page that Hon Pōhiva had not committed nepotism because his son was paid from the Prime Minister's salary.

Maggie Tupou said: 'The way I see it, there is no conflict of interest as his son's wages are paid out of the PM's pocket. It is normal for people to hand pick their own personal assistants.'

Alex Tora said: 'PMs the world over pick their own personal assistants and pay for them from their own pay packets. If that is what PM Pōhiva has done then I do not see any problem with that. I think he is worried about having someone who will not be able to do the job as he wants it done.'

According to Latu, Pohiva managed to change the way Tongans voted. Traditionally they supported a candidate either because they were family or friends, were in the same church or because the candidates wooed them with money and gifts (Latu, 2014a):

Pohiva told voters: 'I have no money to give you so that you can vote for me. I can only afford kava to drink with you while sharing my political views for a country that would serve us better.'

However, Latu said the traditional way of voting had not completely disappeared. It still existed in some places, but most people on mainland Tongatapu and Ha'apai as well as 'Eua had changed their way of voting and only voted for people with appealing policies. It is worth noting a claim made in Tagata Pasifika's coverage of the first democratic election in 2010 that people were still not voting by party, but for candidates who had attached themselves to Pohiva's mana (Tagata Pasifika, 2010a \& b).

Whether Pohiva would have found that statement flattering, or disappointing because it did not suggest a democratically-minded electorate, is difficult to guess. However, while his mana undoubtedly still played a part in 2014, the influence of the diasporic media, the attitudes of the Tongan community in Auckland and the views of the online community all contributed to the change that brought Pohiva and the Democrats to power in Tonga.

\section{Note}

1. Figures correct at 4 April 2016.

\section{References}

Barcham, M. et al (2009). New Polynesian triangle: Rethinking Polynesian migration and development in the Pacific. Asia Pacific Viewpoint, 50(3), 322-337. 
Castells, M. (2008). The new public sphere: Global civil society, communication networks, and global governance. Annals of the American Academy.

de Souza, R. (2014). Ethnic migrant media: Weaving ourselves a home. Unpublished paper presented at the Ethnic Migrant Media Forum, Unitec Institute of Technology, Auckland, New Zealand.

Field, M. (2014a, August 6). Bainimarama heads to Auckland ahead of Fijian elections. http://www.stuff.co.nz/world/south-pacific/10349006/Bainimarama-heads-to-Auckland-ahead-of-Fijian-elections

Field, M. (2014b, December 29). Tonga democracy MP becomes prime minister. www.stuff. co.nz/world/south-pacific/64525253/tonga-democracy-mp-becomes-prime-minister

Georgiou, M. (2002, September-October) Diasporic communities on-line: A bottom up experience of transnationalism. Published as Les diasporas en ligne: une expérience concrète de transnationalisme, Revue Hommes et migrations. www.hommes-et-migrations.fr/index. php?/numeros/migrants_com/1055-Les-diasporas-en-ligne-une-experience-concrete-detransnationalisme

Kailahi, S. (2015a, May). The virtual public sphere: How Tongan diaspora living in New Zealand creates a sense of identity through online and social media. Essay written in part fulfilment of Master of International Communication, Unitec, Auckland.

Kailahi, S. (2015b, June 15). Personal communication.

Karim, K. (1998). From ethnic media to global media: Transnational communication networks among diasporic communities. International Comparative Research Group, Strategic Research and Analysis, Department of Canadian Heritage, Ontario.

Larmour, P. (1994). A foreign flower? Democracy in the South Pacific. Pacific Studies, 17(1), pp45-77.

Latu, K. (2014a, March.). Pohiva: I won because people helped make it happen. Kaniva News. Retrieved from http://nzkanivapacific.co.nz/2014/03/pohiva-won-peoplehelped-make-happen/

Latu, K., (2014b, November 29). PM Pōhiva: We have to prove to His Majesty that we can work together to build Tonga. Kaniva News. Retrieved from http://nzkanivapacific.co.nz/2014/12/pm-pohiva-we-have-to-prove-to-his-majesty-that-we-can-worktogether-to-build-tonga/

Latu, K., (2015a, January 19). Pohiva denies claims of nepotism, says ministers have vowed to put sexual misdeeds behind them. Kaniva News. Retrieved from http://nzkanivapacific.co.nz/2015/01/pohiva-denies-claims-nepotism-says-ministers-vowedput-sexual-misdeeds-behind/

Latu, K., (2015b, February 6). Pohiva tells Auckland meeting: Tongans should learn from Chinese example and live in harmony, Kaniva News. Retrieved from http:// nzkanivapacific.co.nz/2015/02/pohiva-tells-auckland-meeting-tongans-learn-chineseexample-live-harmony/

Latu, K., (2015c, May 17). LDS leader attacks Prince's baptism, charges 'terrorism' and 'bribery'. Kaniva News. Retrieved from http://nzkanivapacific.co.nz/2015/03/ lds-leader-attacks-princes-baptism-charges-terrorism-and-bribery/

Latu, K. (2015d, June 6). Interview with author.

Latu, K. (2015e, June 15). Personal communication with author.

Lee, H. (2004). 'Second generation' Tongan transnationalism: Hope for the future? Asia Pacific Viewpoint, 45(2), pp234-235.

Mann, C. \& Turner, A. (2012, October 19). Rabuka has doubts about 2014 Fiji elections, The Press. Retrieved from www.stuff.co.nz/the-press/news/7838461/Rabuka-hasdoubts-about-2014-Fiji-elections 
Noronha, S. \& Papoutsaki, E. (2014). The migrant and the media: Roles, challenges and potential of ethnic media. Auckland, NZ: Unitec e-press.

Papoutsaki, E., \& Strickland, N. (2008). Pacific islands diaspora media: Conceptual and methodological considerations for a pilot study. Fijian Studies, 6(1 \& 2), pp165-183.

Papoutsaki, E., et al (Eds). (2013). State of media and communication report-Kingdom of Tonga, Port Vila, Vanuatu: PACMAS. www.pacmas.org

Pulu, J. (2015, June). Interview with author.

Pyke, J., Francis, S., et al (2012). The Tongan diaspora in Australia: Current and potential links to the homeland. Report of an Australian Research Council linkage project. Geelong, Vic.: Centre for Citizenship and Globalisation, Deakin University. Retrieved from http://hdl.handle.net/10536/DRO/DU:30047380

RNZI (2014a, June 23). Social media a factor in Cook Islands poll. Retrieved from www.radionz.co.nz/international/pacific-news/247980/social-media-a-factor-incook-islands-poll

RNZI (2014b, June 26). Politicians embrace social media in Cook Islands election race. Retrieved from www.radionz.co.nz/international/programmes/datelinepacific/ audio/2601036/politicians-embrace-social-media-in-cook-islands-election-race

Statistics New Zealand. (2008). Tongan People in New Zealand 2006. Retrieved fromwww.stats.govt.nz/ /media/.../Tongan-Profile-updated-May2008.pdf

Tagata Pasifika (2010a, November 26). Tonga Election 2010, Part 1 of 2. [Television report]. www.youtube.com/watch?v=jczx92Qzwsw

Tagata Pasifika (2010b, November 26). Tonga Election Special 2010, Part 2 of 2. [Television report]. www.youtube.com/watch?v=TQUuUMHDkQg

Tagata Pasifika (2014, November 21). NZ Tongans want to vote in upcoming 2014 election. [Television report]. www.youtube.com/watch? $\mathrm{v}=\mathrm{nV}-7 \mathrm{dM} 6 \mathrm{E} 0 \mathrm{o} 4$

Tagata Pasifika (2015, February 6). Tongan Prime Minister 'Akilisi Pohiva. [Television report] www.youtube.com/watch?v=14wS-ArVUC0

Technology plays a part in election. (2014, June 19). Cook Islands News. Retrieved from www.cookislandsnews.com/item/47250-technology-plays-a-part-in-election/47250technology-plays-a-part-in-election

Tongan media in Auckland (n.d.). Retrieved from www.nichemedia.co.nz/communities_tongan

Utanga. J. (2007). Pasifika media in the digital era. Pacific Journalism Review, 13(1), $19-28$.

Dr Philip Cass is a senior lecturer in the Department of Communication Studies at Unitec, Auckland, New Zealand. His chief geographical areas of research are the Pacific and the Middle East. Dr Cass' main areas of research are in media history, the interaction between religion and the media, developmental journalism, the role of the media and language in independence movements in Melanesia and promoting national identity. He is associate editor and reviews editor of Pacific Journalism Review. pcass@unitec.ac.nz 


\section{Appendix 1: Tongan media in Auckland}

This is a composite list based on a variety of sources and is subject to the usual caveats regarding the functionality of urls and the often fleeting existence of some publications.

\section{Radio stations or stations with Tongan content in Auckland}

Planet FM www.planetaudio.org.nz

NiuFM www.niufm.com/

Radio531pi

www.radio531pi.com/on-air/community-language-shows/2010/11/le-o-eotu-felenite myradiostream.com/radiotonganz (online)

Tonga on the Airwaves (Tama OhiFM) (East \& Bays Courier August 3, 2011) www.radioheritage.net/Story214.asp

Wave of the Pacific 87.8FM

Le'o 'oe Huelo Koula 87.5FM

Le'o 'oe Tapuaki 87.5 FM

en.wikipedia.org/wiki/List_of_radio_stations_in_Auckland

\section{TV in Auckland}

Pacific TV (via Facebook)

Tagata Pasifika tvnz.co.nz/tagata-pasifika; YouTube channel www.youtube.com/user/tagatapasifika1

\section{Newspapers in Auckland}

Taimi'o Tonga was originally published in Auckland, but is now produced in Tonga. An edition is still published in Auckland for distribution to New Zealand, Australia and the US.

\section{Online platforms}

Matangi Tonga matangitonga.to

Taimi Media Network/Taioi Online www.taimionline.com

Planet Tonga www.planet-tonga.com

Kaniva News www.kanivatonga.co.nz

\section{Radio station available by streaming from Tonga}

Radio Tonga A3Z

Millenium Radio

Letio Faka-Kalisiatane 